\title{
ПОЛІТОЛОГІЯ
}

УДК 32.001(15)-04

DOI: $10.21564 / 2075-7190.37 .133320$

Herasina Liudmyla Mykolaivna, Doctor of Sociology Sciences, Professor,

Professor of the Department of Sociology and Political Science of the Yaroslav the Wise National Law University, Kharkiv, Ukraine e-mail: kafsoc@ukr.net

ORCID ID: 0000-0002-3299-5255

\section{CONCEPT AND TENDENCIES TO THE DEVELOPMENT OF THE WORLD POLITICAL PROCESS}

In the article is substantiated that the world political process of the present day is a consolidated activity of all participants of the international relations in the context of globalization changes. In the "world-politics» paradigm, this process is represented as a function of a heterogeneous mega system, which has a political, economic and value heterogeneity of elements on the ground of unstable dialectical interaction. The processes of world politics are characterized not only by the combination of humanity's efforts to overcome global problems, but also by the turbulence of development and contradictory trends (consolidation and disintegration) through the competition of global «centers of influence» and other subjects-players of global politics.

Keywords: world political process, world politics, international system, global politics, national interest, geostrategy, European integration.

Problem setting. The processes of world interaction have ancient roots in human civilization, going back to the era of Antiquity, when Alexander the Great conquered the world, and the Roman Empire affirmed its hegemony in the Mediterranean. The globalized modern world demonstrates that it is politics, as a universal phenomenon, plays a decisive role in the sphere of international relations, where 
the fundamental basis consists of the international political relations of interdependence and interaction of the subjects of the world system. The scientific understanding of the «world political process» is, in most cases, of a modern dimension, and requires, as an integrated global process, of a doctrinal analysis of the essence and tendencies that reflect the diverse activities of sovereign states and other legitimate bodies, movements and organizations of the world (or continental) scale.

Analysis of the main sources and theories. The conceptual foundations of the world political process include the «world-system» analysis» by I. Wallerstein [1-6] and the theory of J. Galtung [7; 8]; it was they who introduced a new concept of «world politics» and «world-economy» to the scientific circulation. Within this theory, the world political process and its evolution are represented by the function of a heterogeneous mega system, characterized by the political and economic heterogeneity of the constituent elements and their dialectic, multipolar interdependence. In today's analytics, understanding of the essence and trends of globalization is primarily due to the creation of new transnational systems and formats (in economics, finance, science, information, etc.), which ensures the domination of capital and information freedom over national interests, especially in pool of the so-called «non-western» countries [9-13].

In the scientific discourse it is traditionally was used the notion of «international system» to analyze diplomatic relations between states in a certain historical period in separate regions of the world: for example, the European (Westphalian) system of the XVII-XVIII centuries; the system of political balance of the European states of the XIX century. («The European concern of the nations»); the global bipolar interstate system of 1945-1991 [14, p. 158-159]. The specificity and the disadvantage of this «panoramic approach», unlike the procedural, was that it was not aimed to find the regularities of the functioning of international systems and interstate processes, usually limited to a description of the historical interaction between their main actors - great states [15, p. 82].

Hence, the purpose of this article is to substantiate the scientific hypothesis that the modern world political process is a consolidated political activity of all participants in international relations in the face of real globalization changes; and is dialectically characterized by contradictory trends as the global competition of global «centers of influence» and subjects-players of global politics, and the combination of humanity's efforts in the main spheres of being.

Presentation of the main materials. Conceptually, the category «world political process» and international relations are closely interconnected; they meaningfully designate one and the same sociopolitical reality, but characterize it in different paradigms. Thus, the world political process essentially reveals the functional aspects of international relations, primarily, the activities of global policy subjects in the international arena. In the course of the world political process in our time 
takes part about two hundred sovereign states, to its events billions of people is involved. Today, is near completion the transition from bipolar to multipolar world, with relative preservation of the dominant position of the United States of America. The controllability of world politics has increased somewhat, although there is a complex, two-way process of globalization of political and economic ties [16, p. 535]. The problems of strengthening global security against the challenges of international terrorism, and attempts to eliminate the phenomenon of war on humanity have become dominant.

The specificity of the content of global politics is that it does not recognize formal barriers, easily overcomes state borders, limits sovereignty and is able to influence the organized communities of people anywhere in the world. The political peculiarity of globalization is the apparent weakening or reduction of the sovereignty of national states; therefore, no country in the world today has full independence [17-20]. These processes are directly related to the strengthening of the centers of world power; in particular, modern states more and more powers delegate to influential international organizations such as the United Nations, NATO, the WTO, the EU, and the IMF. Another factor is that due to the limitation of government interference in the economy and the deregulation of business, the political and economic impact of transnational corporations and large banks (TNCs and TNBs) is increasing. And as a result of the growth of the migration of people and the free movement of capital abroad, the volume of state power in relation to its citizens decreases.

At the same time, the world political sphere characterizes the democratization of the basic branches of life of peoples and states, the growth of the international role of representative powers, movements and influential public figures in world politics. Therefore, the praxeology of the world political process is revealed by the common activity of the actors of world politics and the subjects of international law (states and their governments, intergovernmental unions and non-governmental world organizations), which is aimed at developing mechanisms for harmonizing and balancing national interests, solving problems of survival and progress of mankind, avoidance of wars and counteraction to international terrorism, global and regional conflicts, the establishment of a just world order [21].

Global problems of the world political process in our time are mostly solved by two «clubs» of world politics and world economy - Group of Seven (G7) and Group of Twenty (G20), and also the Davos Forum, BRIC whose sphere of influence mainly includes political and economic issues. As it is generally known, these global political and macroeconomic structures are not formalized in accordance with international law, but their significance in global processes is constantly increasing. At their forums, representatives of states - world and regional leaders discuss and coordinate positions in the field of implementation of political and 
economic processes in the world. This flexible format, not too burdened with legal obligations, allows leading world actors to work out new mechanisms for the «balance of interests» of states and consolidate their efforts in confronting the global challenges of our time.

In the aspect of real politics, world processes are aimed at solving global problems of civilization: issues of war and peace; the overall security of mankind under the conditions of the arms race and climate challenges; environmental protection and the equitable distribution of survival resources; protection of human rights and freedoms; preservation of the world historical and cultural heritage; the fight against international terrorism and crime; overcoming backwardness, poverty and hunger on the «world's outskirts»; prevention of dangerous diseases, epidemics and pandemics, etc.

An important feature of the world political process lies in the fact that it does not have a single, legitimate «center of coercion» with the corresponding political and legal competence, that is, the source of world power with unquestionable authority among all subjects of international relations. Accordingly, as a separate branch of political-legal relations, world politics is regulated by a conglomeration of different norms - international legal, political-historical, ceremonial, business, moral-ethical, even conventional (traditional), etc.

The main peculiarity of the world political process of the present day is seen in the simultaneous action of two contradictory tendencies - consolidation (unification) and disintegration (delimitation) of global actors [22, p. 43-44].

The consolidation tendency manifests itself in the objective process of forming the mass of world productive forces, internationalization of economic activity in the scale of regions and the whole world, the rapid development of the scientific and technological revolution, and the integration of production and non-productive factors in relation to global influences, in the gradual evolution of humanity towards democratization of politics, in modernization spheres of informatization and management of macroeconomic and technological innovations, etc. The second tendency - disintegration - is characterized by centrifugal processes, which are conditioned by the simultaneous existence on the planet of peoples and countries that are at different stages of civilization or formative development. They strive to delimitation because of enormous differences in culture and religion, in terms of welfare, employment, education, with medical care providing, life expectancy, because of political and legal development problems, and national-ethnic divisions. These factors are naturally and historically disintegrating; they inevitably generate alienation among people, distrust between states and, as a result, disputes, conflicts, and wars.

The last years of the XXI century designated by the fact that the vectors of the world political process are constantly migrating and changing. Thus, on the one 
hand, in political and world economic relations, the features of disintegration, even the economic and political isolation of some international subjects (in relation to aggressors, autarky) noticeably increasing gap in the economic development of the states-world leaders and countries-outsiders in the economic development of world leaders and countries-outsiders. But on the other one, the course of the world politics is under the influence of ever more powerful integration tendencies of globalization of the economy, information, the humanitarian sphere, even world churches, spreading of democracy practices, the protection of human rights and freedoms, in particular, more and more dynamically is developing the world market of resources, energy, products, services and labor, and revolutionary breakthroughs in scientific and technological progress [23].

The content of the world political process the most deeply reveals the concept of national interest, which defines the external foreign policy of sovereign countries In politics, group or of common significance interests are always present, and in global, international politics - first of all, national interests. The questions arise: what do induce the state to take certain steps in the international arena? For the sake of what do they enter into relations with other countries? If public needs are to ensure public safety and decent conditions for the country development; then national interest is awareness and reflection in the activity of political elites (leaders) of the indigenous needs of a sovereign state, of its national security and selfpreservation of a political nation.

In this aspect, the problem of «balance of forces and interests» in global politics is exacerbated as a factor of stability or instability. Its actuality is growing because there are no permanent hierarchies of subjects in the world's processes (that is, central power), but there is a large number of sovereignties that are equal and, therefore, do not recognize another supreme authority). It is this gives rise to the international instability and turbulence. Former US Secretary of State Henry Kissinger noted, that in an international system characterized by the presence of five to six great powers and a whole number of smaller countries, the order should mainly appear (as in past centuries) on the basis of reconciliation and balancing rival national interests [24].

The choosing of a strategic line of the state development ultimately depends on the political will of the elite and the people. This choice is a long-term «geopolitical project» of the country, the direction of action and the art of active self-realization (or intervention) of the people on base of their own civilizational identity. National geostrategy involves the neutralization of the destructive consequences for society and state of external and internal challenges from the multidimensional world space. Among the classical geostrategies that are known in world politics are -Continentalism, Atlanticism, Pan-Slavism, Eurasianism, Panamericanism, Islamism, East Asian, Panarabizm and others. 
Modern Ukraine, strengthening foundations of its national interests and priorities of national security, has chosen geostrategy of European integration, and strives to join the geopolitical project of «United Europe». In the present day international situation this choice is due to the degree of post-industrial development of the country and the maturity of civil society [25]. It is also connected with the counteraction of military aggression in Ukraine, the prevention of catastrophes on the so-called energy saturated borders, with the development of communication and socio-economic breakthrough technologies.

The main ideas of European integration geostrategy are as follows: pluralistic democracy, legal and social state, liberalization of the economy, free civil society, European cultural values, free mass media, political-legal consensus in foreign policy, etc. Its strategic objectives are an open policy of democratic reforms, the fight against corruption and the oligarchy, information freedom, economic, political, legal, technical and humanitarian cooperation with the European Union - necessary for the modern Ukrainian society and bring the country closer to the progressive world [26;27].

So, the world political process of the present characterizes:

- a complex set of civilizational, transnational and peripheral, regional, national and local, ethnopolitical processes;

- value and active diversity of political development; growth of experience, directions and forms of international cooperation;

- placing on the first plan of the world politics the global challenges (challenges) of the existence of human civilization;

- growth in the system of universal values of the role of human rights, freedoms and human life interests;

- the diversity of political forces, social forms, means and methods of implementing world politics; the presence of a conventionally coordinated center whose functions belong to United Nations;

- productive interaction of the «Great Seven» states and the European Union; the activity of the important international institutions - the IMF, the WTO, NATO, UNESCO, etc.;

- the contradictory tendencies of the movement to a multipolar (or unipolar) world; the conflicts of relations between the world's "centers of influence» (the USA, Western Europe, Russia, China, Japan, the «new industrialized countries» of the East);

- contradictions between countries and peoples on the basis of the «conflict of civilizations» (Western, Eastern, Islamic, Christian, Slavic, etc.);

- contradictory of the ways of realizing world processes: continuity and innovations, certainty or unpredictability, orderliness or spontaneity; the interweaving of revolutionary and evolutionary tendencies. 
Conclusions. Thus, the essential content of the global political process, developing at the global and regional levels, defines the practices of state-political institutions, international organizations, large social communities and influential politicians with international authority. The leading criterion for progress in world politics was the movement of peoples and states by the way of democratization (the «fourth wave» of modernization). As the evolution of a civilized society leads to the formation of a democratic civil society with real economic, political, social rights and freedoms, to the development of a legal, social state with political pluralism, the division of competences of state power, powerful local self-government, with a developed national culture, a high level of well-being and social protection of the population.

\section{REFERENCES}

1. Wallerstein, I. (2011). The Modern World-System. Vol. IV: Centrist Liberalism Triumphant, 1789-1914. Berkeley: University of California Press.

2. Wallerstein, I. (1979) The Capitalist World-Economy: essays. Cambridge [Eng.]; New York: Cambridge University Press.

3. Vallerstayn, I. (2004). Konec znakomogo mira: Sociologija XXI veka. Moskva: Logos [in Russian].

4. Vallerstayn, I. (2006). Myrosystemniy analyz: Vvedenye / per. N. Tyukynoy. Moskva: Yzdatel'skyy dom «Terrytoryia budushcheho» [in Russian].

5. Vallerstayn, I. (2006). Geopoliticheskiye razmezhevaniya v XXI stoletii. Ekonomicheskiye strategii - Economic Strategies, 5-6, 14-23 [in Russian].

6. Wallerstein, I. (2009). Where Does the World Go? EUROPE. Warszawa. Vol. 9, issue 2(31), 61-67.

7. Galtung, J. (1968). Small Group Theory and the Theory of International Relations. A Study in Isomorthism. New Approaches to International Relations / Ed. by M. Kaplan. New York: St. Martin's Press. 270-295.

8. Tsyigankov, P. A. (1998). Yohan Galtung, neomarksizm i sotsiologiya mezhdunarodnyih otnosheniy. Sotsialno-politicheskiy zhurnal - Socio-political magazine, 2, 37-39 [in Russian].

9. Soloviyov, E. G. (2001). Analysis of geopolitics of international problems of contemporaneity. Pro et Contra. The Political researches, 6, 116-130 [in Russian].

10. Morgenthau, H. J. (1967). Politics among nations; the struggle for power and peace. 4-th ed. New York: Knopf.

11. Fiero, G. K. (1998). The Clobal Village of the Twentieth Century. New York: McGrawHill.

12. Krupka, I., Pankiv, H. (2013). Modern International Requlatory Requirements For Banks Liquidity. Bisnesinform, 6, 337-341.

13. Panchenko, M. (2009). Neklassicheskie paradigmy izucheniya miroporyadka. VlastPower, 4: 37-45 [in Russian]. 
14. Huntzinger, J. (1987). Introduction aux relations internationales. Paris: Seuil.

15. Herasina, L. M. (2016). Istoryko-politychna evoliutsiia mizhnarodnykh system: sutnist, zakonomirnosti, typy. Visnyk Natsional'noho universytetu «Yurydychna akademiya Ukrayiny imeni Yaroslava Mudroho». Seriya: politolohiy - The bulletin of National University «Yaroslav the Wise Law academy Ukraine». The series of political science, issue 2 (29), 80-95 [in Ukranian].

16. Herasina, L. M. (2015). Polityka svitova. Politolohichnyi entsyklopedychnyi slovnykPolitical Encyclopedic Dictionary / Uklad.: L. M. Gerasina, V. L. Pohribna, I. O. Polishchuk ta in.; za red. M. P. Trebina. Kharkiv: Pravo. 534-536 [in Ukranian].

17. Bauman, Z. (2008). Hlobalizatsiia: naslidky dlia liudyny i suspilstva / per. z anhl.: I. V. Andrushchenko. Kyiv: Kyievo-Mohylianska akademiia [in Ukranian].

18. Bzhezinskiy, Z. (1998). Velikaya shahmatnaya doska. Moskva: Mezhdunarodnyie otnosheniya [in Russian].

19. Bazhanov, E.. Bazhanova, N. (2009). Kuda idet chelovechestvo? O tendentsiyakh mezhdunarodnykh otnosheniy v XXI veke. Obozrevatel-Observer, 6, 10-15 [in Russian].

20. Panarina, N. N. (2010). Globalizatsiya: tendentsiya i protivorechiya (kontseptualnyiy analiz). Teoriya i praktika obschestvennogo razvitiya - Theory and practice of social development, 1, 37-42 [in Russian].

21. Engibaryan, R. V. (2007). Konstitutsionnoe razvitie v sovremennom mire. Osnovnyie tendentsii. Moskva: Norma [in Russian].

22. Herasina, L. M. (2017). Svitovyi politychnyi protses: kontseptualnyi aspekt i realna polityka. II Kharkivski mizhnarodno-pravovi chytannia: Zb. naukovih statei. Chast I. Kharkiv: Natsionalniy Yurydychniy Universytet im. Yaroslava Mudroho. 41-46 [in Ukranian].

23. Herasina, L. M. (2014). Hlobalizatsiini protsesy yak vyklyky svitosystemnii strukturi. $V$ isnyk Natsional'noho universytetu «Yurydychna akademiya Ukrayiny imeni Yaroslava Mudroho». Seriya: Filosofiya, filosofiya prava, politolohiya, sotsiolohiya - The bulletin of National University "Yaroslav the Wise Law academy Ukraine». The series of philosophy, philosophy of law, political science, sociology, issue 4(24), 241-244 [in Ukranian].

24. Kissindzher, G. (2002). Nuzhna li Amerike vneshnyaya politika? /Pod red. V. Inozemtseva. Moskva: Ladomir [in Russian].

25. Mykhalchenko, M. I. (2004). Ukraina yak nova istorychna realnist: zapasnyi hravets Yevropy. Drohobych; Kyiv: Vidrodzhennia [in Ukranian].

26. Dergachev, V. (2004). Tsivilizatsionnaya geopolitika (Geofilosofiya). Kiev: VIRA-R [in Russian].

27. Herasina, L. M. (2015). Problema vyboru heostratehii suchasnoiu Ukrainoiu v heopolitychnomu landshafti svitu. Visnyk Natsional'noho universytetu «Yurydychna akademiya Ukrayiny imeni Yaroslava Mudroho». Seriya: Filosofiya, filosofiya prava, politolohiya, sotsiolohiya - The bulletin of National University "Yaroslav the Wise Law academy Ukraine». The series of philosophy, philosophy of law, political science, sociology, issue, 3 (27), 210-212 [in Ukranian]. 
Герасина Людмила Николаевна, доктор социологических наук, профессор, профессор кафедры социологии и политологии Национального юридического университета имени Ярослава Мудрого, г. Харьков, Украина

\section{КОНЦЕПТ И ТЕНДЕНЦИИ РАЗВИТИЯ МИРОВОГО ПОЛИТИЧЕСКОГО ПРОЦЕССА}

В статье обосновывается, что мировой политический процесс современности является консолидированной деятельностью всех участников международных отношений в условиях глобализаиионных сдвигов. В парадигме «мир-политики» этот проиесс представлен как функиия гетерогенной мегасистемы, которой свойственны политическая, экономическая и ценностная неоднородность элементов на почве неустойчивого диалектического взаимодействия. Прочессы мировой политики характеризуются не только единением усилий человечества в преодолении глобальных проблем, но и турбулентностью развития, и противоречивыми трендами (консолидаџии и дезинтеграции) из-за конкуренции мировых «центров влияния» и других субъектов-игроков глобальной политики.

Ключевые слова: мировой политический прочесс, мир-политика, международная система, глобальная политика, начиональный интерес, геостратегия, евроинтеграичия.

Герасіна Людмила Миколаӥвна, доктор соціологічних наук, професор, професор кафедри соціології та політології Національного юридичного університету імені Ярослава Мудрого, м. Харків, Україна

\section{КОНЦЕПТ І ТЕНДЕНЦЇ̈ РОЗВИТКУ СВІТОВОГО ПОЛІТИЧНОГО ПРОЦЕСУ}

У статті обгрунтовується наукова гіпотеза, що сучасний світовий політичний процес є консолідованою політичною діяльністю всіх учасників міжнародних відносин в умовах реальних глобалізачійних зрущень. У дослідницькій парадигмі «світполітики» иеей процес представлений як функиія гетерогенної мегасистеми, якій властиві політична, економічна і иүіннісна неоднорідність елементів на трунті нестійкої діалектичної взаємодії.

Процеси світової політики в умовах глобалізачії характеризуються новими трендами - глобальною конкуренцією світових «центрів впливу» та інших суб'єктів-гравиів глобальної політики; і водночас поєднанням зусиль людства у подоланні глобальних проблем буття. Праксеологію світового політичного процесу розкриває сукупна діяльність а́кторів світової політики і суб'єктів міжнародного права - держав та їх урядів, міжурядових союзів і неурядових світових організачій. 
Розуміння суті й трендів глобалізащії пов'язане зі створенням нових транснаціональних систем і форматів (в економіці, фінансах, політиці, науці, інформації та ін.), щуо забезпечує домінування капіталу й інформаційної свободи над національними інтересами, особливо в пулі так званих «незахідних» краӥн. Політична особливість глобалізації-цуе очевидне послаблення чи скорочення суверенітету національних держав. Але більи домінантними стали проблеми змічнення глобальної безпеки перед викликами міжнародного тероризму, та спроби усунення феномену війни з життя людства. Глобальні проблеми світового розвитку переважно вирішуються так званими «клубами» світ-політики і світ-економіки - G7 i G20, СC, а також Давоським Форумом, ШОС, БРІКС та ін. Цей формат не дуже обтяжений юридично і дозволяє світовим а́кторам виробляти механізми «балансу інтересів» та консолідацї держав щуодо протистояння глобальним викликам сучасності.

Світовому політичному процесу діалектично властива певна турбулентність розвитку і дія суперечливих тендениій: консолідації й дезінтеграції. Перша - проявляє себе у формуванні масиву світових продуктивних сил, інтернаціоналізації економічної діяльності, у стрімкому розвитку НТР, в осучасненні сфер інформатизації та управління відносно глобальних впливів, у поступовій демократизації політики. Тенденція дезінтеграції позначає відчентрові процеси, обумовлені одночасним існуванням на планеті народів і краӥн, щзо перебувають на різних стадіях циивлізаційного розвитку. Але з поч. XXI cm. вектори світового політичного процесу постійно мігрують $і$ змінюються.

Обрання стратегічної лінії розвитку держави цілком залежить від політичної волі еліти та народу; ичей вибір - довгостроковий «геополітичний проект» краӥни. Національна геостратегія передбачає нейтралізачію руйнівних для держави наслідків від зовнішніх і внутрішніх викликів з боку багатомірного світового простору. Сучасна Украӥна, змічнюючи свої національні інтереси і національну безпеку, обрала геостратегію євроінтеграції, щзо передбачає - плюралістичну демократію, правову державу, лібералізацію економіки, сильне громадянське суспільство, європейські иінності, вільні мас-медіа, консенсус у зовнішній політиці тощо. Ї̈ стратегічні ияілі - відкрита політика демократичних реформ, боротьба з корупиією та олігархією, інформаційна свобода, розвиток економічної, політико-правової, техніко-комунікаційної та гуманітарної співпраці з Свросоюзом.

Таким чином, провідним критерієм прогресу в світовій політиці стає рух народів і держав иляхом демократизації («четверта хвиля» модернізації); а майбутній зміст світового політичного процесу, щуо розгортається на глобальному рівні, залежить від практик державно-політичних інститутів, міжнародних організацій, великих соиіальних спільнот і впливових політиків, які мають міжнародний автоpumem.

Ключові слова: світовий політичний процес, світ-політика, міжнародна система, глобальна політика, національний інтерес, геостратегія, євроінтеграція. 